\title{
Some Rare and Interesting Sea Anemones from Plymouth.
}

\author{
By \\ Chas. L. Walton and Olwen M. Rees, B.Sc., \\ University College of Wales, Aberystwyth. \\ With Figures 1 and 2 in the Text.
}

THE anemones described in the following pages were collected by Mr. J. H. Orton, and forwarded for examination.

I. Edwardsia timida, Quatrefages.

Quatrefages obtained his specimens at Chausey, Manche, N. France, and his descriptions of E. timida and $E$. harassi as new species appeared in 1842 ("Ann. des Sci. Nat." (2), XVIII). G. Y. Dixon obtained eight specimens at Malahide, Co. Dublin, and these he carefully described in 1886 ("Proc. Roy. Dublin Soc."). He also united Quatrefages' two species as E. timida. In 1889 A. C. Haddon supported Dixon's opinions and identification, gave a good figure of the mesenterial muscle characters, and contrasted these with three other British species ("Proc. Roy. Dublin Soc.").

Through the kindness of Dr. E. J. Allen and Mr. J. H. Orton, B.Sc., we have been able to examine and identify a specimen from Plymouth Sound, obtained May 22nd, 1912. This specimen was examined when alive, when killed expanded, and also anatomically by means of transverse sections.

Size.-Measurements during life were difficult to obtain as the Anemone was very timid and remained buried in sand, only expanding the tentacular crown at the surface. The latter was $12 \mathrm{~mm}$. in diameter. When killed in an expanded condition, the total length was $41 \mathrm{~mm}$.; length of capitulum $9 \mathrm{~mm}$., diameter 3.5 ; diameter of scapus $4 \mathrm{~mm}$.

Form.-Physa not large, and when partially invected showed eight well-marked divisions; no attached sand grains. Scapus elongate, cylindrical, tapering below and somewhat inflated at the summit, covered by a thin coat of mucus and a number of attached sand grains; body-wall slightly wrinkled transversely and divided into eight regions. 
by the grooves along the insertion of the mesenteries; there is a tendency to folding, and suckers are present on the upper portion. The capitulum, arising from the scapus by a gentle slope, was retractile, delicate, and smooth. Disk concave; mouth raised on a cone. Tentacles 16 in number, of fair length and somewhat obtuse ; at first sight there appeared to be 17 tentacles, but this was due to the fact that one was bifurcate near the summit.

Colour.-Investing coat yellowish ; during distension, the mesenteries showed through the integuments as white longitudinal lines. Disk light brown, freckled with yellowish white spots, the eight radii yellowish white with a dark central line; lips of a darker shade of brown than the disk and with a circle of eight reddish brown spots. Tentacles pellucid, freckled, and indistinctly and irregularly barred and blotched with white, and with a few distinct madder-brown or chocolate spots, which tended to become bars near the tip : at the base of one of the tentacles was a white spot. The colouration of the disk and tentacles harmonized so exactly with that of the sand amidst which the Anemone was living as to render it by no means easy of detection, even when fully expanded.

Anatomy.-Transverse sections showed muscle characters practically identical with those figured by Haddon. The ectoderm is thin, and broken in many places; the mesogloea is fairly thick, not very dense, and contains here and there lenticular spaces of no great size; these stain deeply. The endoderm is of about the same thickness as the mesogloea, and both broaden in the regions between the insertion of the mesenteries.

The specimen was a female, and the mesenteries were all gonophoric. In the basal muscle the mesogloea shows eight to ten folds on either side, many of them branched; the longitudinal muscles large and with from eighteen to twenty folds, a number of which are more or less branched; all are fringed, giving them much the aspect of fern fronds. The ova occurred as more or less compact masses.

\section{Edwardsia claparedi, Panceri, 1869.}

Haddon (1889) suggested that the Edwardsia which Kingsley found washed up at Torquay in 1854, and which was described by Gosse (1860, p. 262) as "? Edwardsia beautempsii (Quatref.)," may have been $E$. claparedi. After stating his belief that E. callimorpha, Gosse, is identical with $E$. beautempsii, Quatrefages, Haddon enumerates the points of difference between that species and the specimen in question as given by Gosse, and concludes : "In the above particulars this Edwardsia 
agrees so well with the description and beautiful figures of $E$. claparedi (Panceri) given by Professor Andres (Le Attinie, p. 90, pl. xi.) that we may with justice, for the present, allocate it to that species."

After examination and comparison of both external and anatomical characters, we are able to identify as $E$. claparedi two specimens from Plymouth; and the species can thus be added to the British Fauna. with certainty.

Of the two specimens just mentioned, one (A) was kept alive for a considerable time at Plymouth, was safely sent to us at Aberystwyth, and remained in a healthy condition, living buried in sand in a shallow dish. When first received it was very timid and remained buried for twenty-four hours, expanding at first only by night, and closing rapidly at the least vibration. Later it would remain expanded during daylight and for much longer periods, and it also became much less sensitive to movements in its vicinity. Both specimens were obtained from Jennycliff Bay, Plymouth Sound.

Size.-It was impossible to obtain complete measurements of (A) during life, as it remained buried, and if uncovered retracted and at once commenced to bury itself by the use of the physa. When partially anæsthetized the total length was $50 \mathrm{~mm}$. ; greatest diameter of scapus $7.5 \mathrm{~mm}$. ; of capitulum $4 \mathrm{~mm}$. ; the physa was 4 to $5 \mathrm{~mm}$. in length and breadth; and the expanse of the tentacular crown 12 to $13 \mathrm{~mm}$. The physa was rounded, delicate in texture, and almost transparent. Scapus cylindrical, fairly stout, tapering downwards to just above the physa, ringed and folded during partial retraction; grooved by the insertion of the mesenteries, with the intervening ridges warted. Scapus covered by a thin cuticle which is thickest on the ridges and about the warts; these latter occur in a linear row on each ridge and are seldom contiguous ; the upper third of the scapus is bare of cuticle and the warts are fewer and finally disappear. The capitulum and upper portion of the scapus can be retracted within the remainder of the scapus, and this movement can be very rapidly effected. The tentacles are sixteen in number, slender, tapering, about twice as long as the diameter of the disk ; held in a most irregular manner as a rule, some extended, others flexed, others bent in a contorted manner across the disk; occasionally all are regularly extended, the tips bent inward (as shown in Fig. 1).

Colour.-Physa almost transparent. Cuticle rust-red, but darker where thickest (as around the warts). On the summit of the warts the cuticle is frequently missing and they then appear as pale spots. Capitulum dull opaque flesh colour, near the summit is an indistinct white 
ring, and above this an indistinct circle of purple. Disk fawn, with some orange mottlings about the mouth region; an indefinite white area runs from the base of the two opposite "gonidial " tentacles toward the lips, and from the bases of the remaining six tentacles of the primary cycle run similar indistinct black bars, these radial markings divide the rest of the disk into eight more or less irregular fawn-coloured, triangular areas; the mesenteries also show as pellucid white lines. Mouth usually

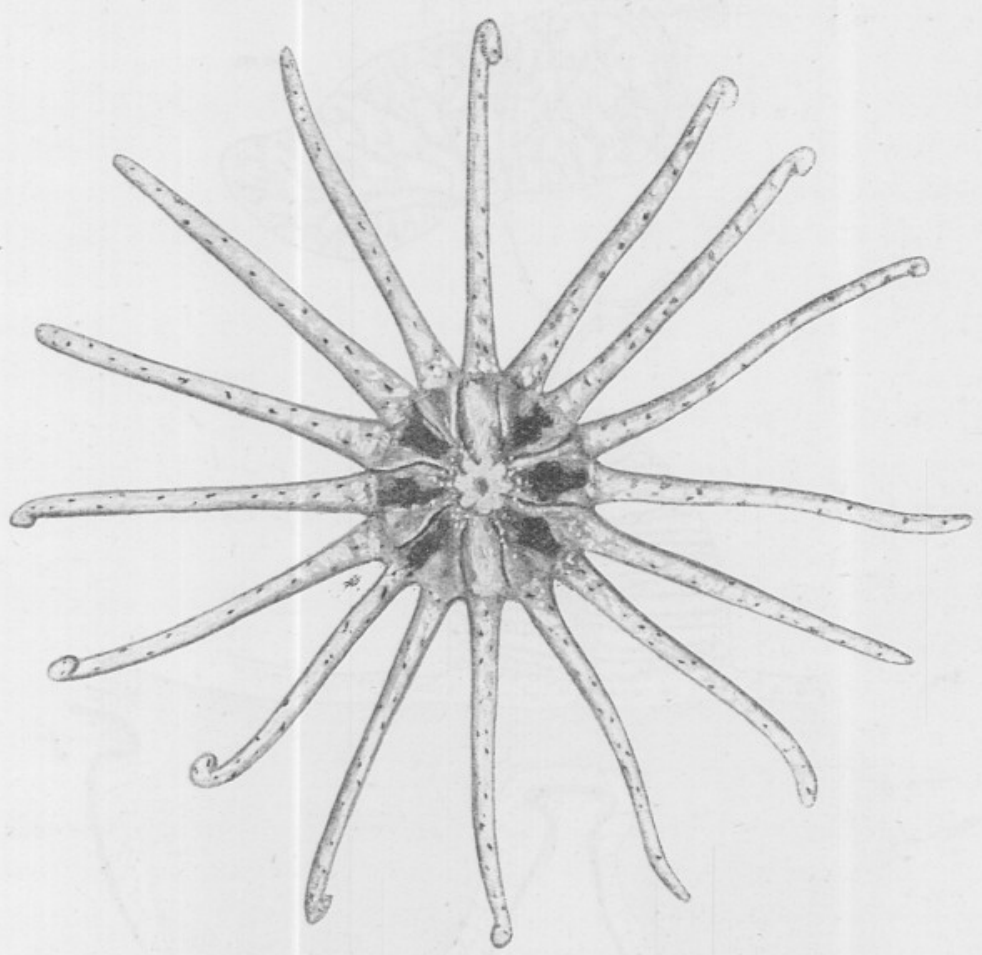

Fic. 1.-Edwardsia claparedi. Oral disk (greatly enlarged).

elevated, lips pale. Tentacles translucent, blotched with opaque-white and speckled with small red dots, the tips white: the white mottlings appear mainly on the front face.

Specimen (B).-A preserved example, obtained from mud, Jennycliff Bay, April 12th, 1912. It was strongly contracted, and-somewhat damaged. Cuticle thin and brownish in colour, the mesenteries showed here and there through the body-wall in an indistinct manner ; capitulum and physa invected ; eight warted ridges were present, but not so strongly developed as in the last example. Length $28 \mathrm{~mm}$., breadth about $8 \mathrm{~mm}$. 
We have compared these Plymouth examples with preserved specimens of E. claparedi obtained from the Naples Marine Biological Station, and find both external and internal characters in agreement. The following is a short description of the external characters of one of the best of the Italian specimens :

Length (somewhat contracted) $45 \mathrm{~mm}$., greatest diameter $5 \mathrm{~mm}$. Physa small, being slightly contracted, about $1.5 \mathrm{~mm}$. in length. Scapus

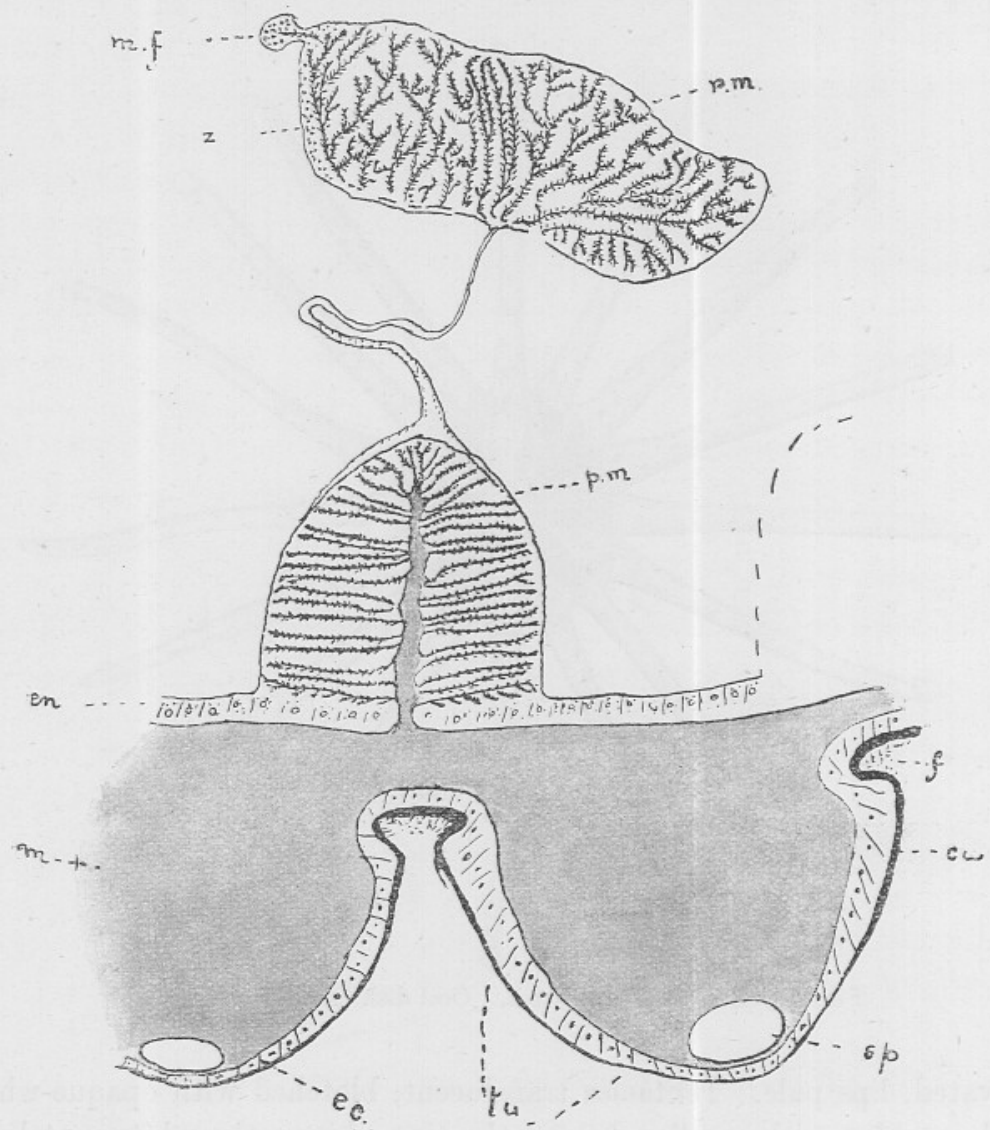

FIG. 2.-Edwardsia claparedi. Part of transverse section throngh the scapus regio showing tubercles, body wall, and mesentery (slightly diagrammatic). Index to lettering: $c u$, cuticle ; ec, ectoderm; en, endoderm; $m$, mesogloa; m.f., mesenterial filament; $f$, foreign incrustations on the body-wall ; sp., space at summit of tubercle; $p . m$. , parieta muscle; r.m., longitudinal retractor muscle ; $t u$, tubercle ; $z$, zooxanthellae.

cylindrical, tapering at either extremity, coated by a wrinkled, orangecoloured epidermis, and beset with eight longitudinal rows of whitish warts, devoid of covering at their summits ; they are set more closely 
together on the upper third, but scarcely ever contiguous. Disk narrow, mouth pouting. Tentacles 16 , obtuse, wrinkled, contracted to a length of $3 \mathrm{~mm}$.

All specimens likewise agree with the figures and description of Andres, and the plate given by Delage and Hérouard in Zoologie Concrète. The colouration of this species is evidently extremely variable to judge by the figures and descriptions of Andres in L'Attinie.

Anatomy.-Transverse sections of the two British and an Italian example revealed practically identical characters. (B) was strongly contracted and somewhat injured and gave very indifferent results when sectionized. Sections showed the cuticle and a thick but irregular ectoderm (Fig. 2) ; the mesoglœa of the column wall is comparatively thin in the capitular region, but becomes very dense and much thicker toward the physa end; the warts consist of outgrowths of the mesoglœa and are frequently hollow, being then capped by a thin layer of mesoglœa and ectoderm. All eight mesenteries are fertile; the retractor muscle is large and the basal muscle comparatively small in the region bearing the gonads; lower down, the retractor becomes smaller, and the basal muscle larger, and in the region of the physa the two are of about equal size. The folds of the basal muscle are about twenty in number on each side and are often bifurcated, the proximal fold gives off numerous small branches on its outer edge ; the folds are long and slender and lie practically at right angles to the central strand of mesoglœa, which appears in section as a fairly stout rod, branching out at its distal end. The longitudinal retractor muscle is reniform in section, but the folds are not as stout nor have they the peculiar moss-like appearance seen in E. timida; they are fairly slender, very much branched, and are from fifteen to twenty in number. We are indebted to Mr. F. S. Wright for a figure of this Anemone in the living condition (Fig. 1).

\section{Halcampa chrysanthellum, Peach.}

Originally described by Peach and Gosse from Cornish specimens, and regarded as the only British species until Haddon discovered $H$. arenaria in S.-W. Ireland in 1885 and 1886. As the two species bear a considerable external resemblance it is more than likely that there has been some confusion in identification. Haddon identified specimens from the East of Ireland as $H$. chrysanthellum, with certain anatomical characters, but he pointed out that, until specimens from the original Cornish localities had been examined anatomically it would be unsafe 
to assume actual identity. If the Cornish form should prove to be identical with the Irish specimens considered to be $H$. chrysanthellum by Haddon, well and good; it is also possible that $H$. arenaria has a much wider range. Meanwhile many identifications can only be accepted provisionally. British records of $H$. chrysanthellum include: Fowey (Peach); Gwyllyn Vase, Pennance, etc. (Cocks); Salcombe (Allen and Todd); River Yealm ("Plymouth Marine Invertebrate Fauna"); Isle of Man (Herdman); East of Ireland (Haddon); Firth of Forth (Leslie and Herdman), etc.

In 1907 one of us examined some twenty living specimens of Halcampa collected in the River Yealm. Considerable variability was noted as to incrusting sand, the retractility and size of the physa, and the colouration. Lack of time unfortunately prevented any further inquiry on that occasion. Recently, however, three preserved specimens collected in. the Yealm were examined and found to agree in all external features. Sections have been cut, and the anatomical characters compared with Haddon's figures of his East Irish specimens and found to be identical. It is noteworthy that both Haddon and Gosse state for this species that the physa is large and non-retractible, and this character should prove to be a useful aid to identification. The following is a description of the external characters of the specimen examined anatomically (preserved in spirit): Total length $20 \mathrm{~mm}$, divided as follows: physa $3.5 \mathrm{~mm}$. long and $3.5 \mathrm{~mm}$. broad, scapus $13 \mathrm{~mm}$. $\times 2 \mathrm{~mm}$., capitulum 3.5 : Physa globular, delicate, semitransparent, studded with small white suckers to which adhered numerous sand grains; Scapus slightly wrinkled; Disk convex, elevated, M-mark on the margin distinctly visible.

In another specimen $31 \mathrm{~mm}$. in length the physa was similar in form and showed the same numerous small white suckers and attached sand grains.

\section{Halcampa arenaria, Haddon.}

This species was described by Haddon in 1886 from specimens obtained from the Kenmare River, S.W. Ireland, 38-44 fathoms (1885), and again, mouth of Bantry Bay, 38 fathoms (1886). We are indebted to Mr. J. H. Orton for a specimen from Rum Bay, Plymouth Sound, November 19th, 1910. He further provided us with some interesting sketches made while the anemone was alive. In his opinion this specimen was $H$. arenaria, and our anatomical examination has proved this to be correct. The following notes describe the specimens after preservation. Total length $38 \mathrm{~mm}$., greatest diameter of scapus $4.5 \mathrm{~mm}$., of 
capitulum less. Body-wall thick, tough and opaque; physa damaged, but appears to be much smaller than in $H$. chrysanthellum, no sand grains were attached, and no suckers were observable with a lens; the small size is well shown in Mr. Orton's sketches, as is also the fact that the physa is retractible in this species, and thus agrees with the plate and description of Haddon (Proc. Roy. Dublin Soc., 1889). The scapus tapers at either extremity, and for a length of $20 \mathrm{~mm}$. is coated with sand grains attached to suckers, and within this portion the physa and capitulum can be withdrawn. The capitulum is smooth, more delicate, and somewhat constricted near the summit.

Colour, pale yellowish buff, the mesenteries showing indistinctly as paler lines. Tentacles and disk much as in H. chrysanthellum; one of Mr. Orton's sketches, comprising a tentacle and portion of disk and mouth, shows the transverse bars, M-mark and the triangular brown patches figured by Haddon; but the form of these brown marks on the disk is different. Instead of being "lenticular" the marks are triangular, with the apex directed toward the tentacle.

Haddon gave a comparison of the anatomical characters of the two species of Halcampa, but a re-statement of the points of difference seems advisable; and ignoring for the present the colouration of the disk and tentacles, the details are here given :-

\section{H. chrysanthellum.}

(1) Physa large, globular, translucent, provided with small white suckers, and not capable of being withdrawn within the scapus.

(2) Scapus smooth.

(3) Number of folds of the muscular epithelium of the longitudinal muscle of the mesenteries, as seen in transverse section, 10 to 12 .

In addition to the above Haddon states that :-

(4) "The oesophagus in section is, relatively to the diameter of the body, much larger in $H$. chry-

\section{H. arenaria.}

(1) Physa smaller, probably without suckers, and retractible within the scapus.

(2) Scapus with suckers to which adhere sand fragments forming a more or less dense covering.

(3) Number of folds of longitudinal muscle about 15 . 
santhellum than in $H$. arenaria." This character is, however, not well marked in our sections.

(5) Also, "In H. chrysanthellum only 6 mesenteries bear generative products." This is the case in our specimen.

(5) "All 12 mesenteries are fertile in $H$. arenaria."

In the specimen we have examined only 10 perfect mesenteries are fertile, those that are barren being those mesenteries of the perfect lateral pairs which are nearest to the sulcar directives (the sulcosulcar laterals of Haddon)

\section{Eloactis mazeli, Jourdan.}

In 1892 Garstang described a living specimen of this interesting Anemone from the Devonshire coast (Trans. Devon. Assoc.). Since then, more or less mutilated specimens have been dredged by the s.s. Oithona from the Inner and Outer Rame-Eddystone trawling grounds; and during May, June, and July, 1912, in particular, a number of examples were brought in. Almost all were much damaged, only the summit of the scapus and oral crowns being present, and these greatly distorted and contracted. Under these conditions, the tentacles being much shortened and strongly capitate, and the colouration very pale, it was only quite recently that their true identity was recognized. Several when examined still showed signs of life. As in the case of Edwardsia claparedi we have compared the Plymouth examples with named material from Naples both as regards external and anatomical characters. The mutilation is evidently due to the habit of lying buried in sand, the oral crown projecting, and thus being cut off by the dredge.

The following is a description of one of the least damaged specimens : Form.-Upper portion of scapus firm and smooth, but with many fine longitudinal ridges and grooves, succeeded by a fosse. Tentacles 20 , set in two cycles of 10 , long and short thus alternating; they consist (in this contracted state) of a stout, transversely wrinkled stalk and a strongly adhesive rounded head. Disk very tumid and much wrinkled; mouth rather large, one strong œsophageal groove. Colour.-Flesh tint, the tentacles marked with brown near the summit; disk orange-pink with somewhat lighter rays. Diameter of disk and tentacles $4 \mathrm{~cm}$. when strongly contracted. Locality, $5 \frac{1}{2}$ miles off Rame Head; 25 fathoms, fine sand; taken in fine-mesh dredge. 
Mr. Orton sends the following notes regarding a specimen obtained from the Outer Rame-Eddystone, July 2nd, 1912: "The tentacles were blotched with brown at the extremity, and several had double purple internal stripes; others appear to have only one coloured stripe ; bodywall orange .... the tentacles were examined but no knobs were visible."

A more detailed description of this species will be found on pp. $70-80$. 